REFERENCES

* Austen, W. G., and Edwards, H. C. (1961). Gut, 2, 158

Beal, J. M., and Dineen, P. (1950). Arch. Surg., 60, 203.

* Beattie, A. D. (1950). Lancet, 1, 525.

Burge, H. W. (1960). Postgrad. med. F., 36, 2.

Burge, H. W. (1960). Postgrad. med. F., 36, 2.

- and Clark, P. A. (1959). Brit. med. F., 1,

$\star$ - Rizk, A. R., Tompkin, A. M. B., Barth, C. E., Hutchison, J. S. F., Longland, C. J., McLennan, I., and Miln, D. C. (1961). Lanost, 2, 897.

* Clark, C. G. (1961). Brit. med. f., 1, 1250

* Crile, G., Jones, T. E., and Davis, J. B. (1949). Ann. Surg., 130, 31.

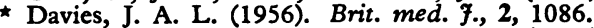

Dragstedt, L. R., and Woodward, E. R. (1951). F. Amer. med. Ass., 145,795 .

^ Edwards, L. W., and Herrington, J. L. (1953). Ann. Surg., 137, 873.

Elliot-Smith, A., Painter, N. S., and Porter, R. (1961). Lancet, 2, 1036.

Faik, S., Grindlay, J. H., and Mann, F. C. (1950). Surgery, 28, 546.

* Feggetter, G. Y., and Pringle, R. (1963). Surg. Gynec. Obstet., 116, 175 .

Franksson, C. (1948). Acta chir. scand., 96, 409.

Frazer, A. C. (1955). Brit. med. f., 2, 805.

Griffith, C. A. (1962). West. ₹. Surg., 70, 175

* Grimson, K. S., Rowe, C. R., and Taylor, H. M. (1952). Ann. Surg, 135, 621 . $\star$ Hamilton, J. E., Harbrecht, P. J., Robbins, R. E., and Kinnaird, D. W. (1961). Ibid., 153, 934.

Harper, A. A. (1959). Gastroenterology, 36, 386.

^ Hendry, W. G. (1961). Postgrad. med. F., 37, 137.

$\star$ Henson, G. F., and Rob, C. G. (1955). Brit. med. f., 2, 588.

* Hindmarsh, F. D. (1957). Lancet, 1, 1113.

* Hoerr, S. O. (1955). Surgery, 38, 149.

* Holt, R. L., and Lythgoe, J. P. (1961-2). Brit. F. Surg., 49, 255.

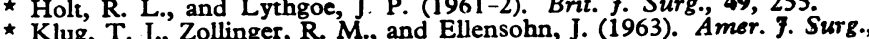

Klug, T. J., Zo.

* Kraft, R. O., Fry, W. J., and Ransom, H. K. (1962). Arch. Surg., 85, 687.

Machella, T. E., and Lorber, S. H. (1948). Gastroenterology, 11, 426.

* MacKelvie, A. A. (1957). Brit. med. f., 1, 321.

* Orr, I. M., and Johnson, H. D. (1949). Ibid., 2, 1316.

* Pollock, A. V. (1952). Lancet, 2, 795.

Ross, B., and Kay, A. W. (1964). Gastroenterology. In press.

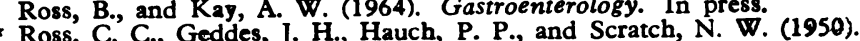
Canad. med. Ass. F., 63, 347.

Roth, H. P., and Beams, A. J. (1959). Gastroenterology, 36, 452.

$\star$ Smith, R. C., Ruffin, J. M., and Baylin, G. J. (1947). Sith. mod. $Y$. (Bgham, Ala.), 40, 1.

Waddell, W. R. and Wang C. C. (1952-3). 7. appl. Physiol., 5, 705.

W Walters, W. and Mobley, J. E. (1957). Ann. Surg., 145, 753.

* Weinstein, V. A. Hollander, F., Lauber, F. U., and Colp, R. (1950). Gastroenterology, 14, 214.

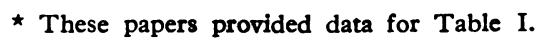

\title{
Aspects of Nutrition after Vagotomy and Gastrojejunostomy
}

\author{
ALAN G. COX,* M.D. ; MICHAEL R. BOND, $†$ M.B., CH.B. ;DENNIS A. PODMORE, $\ddagger$ A.R.I.C. \\ DAVID P. ROSE,§ M.B., CH.B.
}

Brit. med. F., 1964, 1, 465-469

The choice of operation in the surgical treatment of chronic duodenal ulcer remains a controversial subject. Partial gastrectomy is now performed less frequently, as surgeons are increasingly attracted to the advantages of vagotomy, which effects a substantial reduction of gastric-acid secretion in most cases. Recurrent ulceration appears to be more common after vagotomy than after partial gastrectomy, but this disadvantage of vagotomy is balanced and possibly outweighed by the higher post-operative mortality rate after partial gastrectomy. The major criticism of partial gastrectomy is that it leads to an unacceptably high incidence of late complications, which include alimentary symptoms such as postprandial abdominal discomfort, dumping, and vomiting, and also impaired nutrition manifested by loss of weight, anaemia, and more rarely osteomalacia. Although agreement is not complete, many publications support the contention that untoward alimentary symptoms are comparatively infrequent after vagotomy. However, there is remarkably little information in the literature to substantiate the view that impaired nutrition is rare after vagotomy. In order to provide data relevant to this latter problem, this paper reports the results of a study of patients after vagotomy and gastrojejunostomy for chronic duodenal ulcer.

Vagotomy has been extensively used in Sheffield since 1958, and the interval between operation and the present review varied between 37 and 57 months in the patients studied; we have therefore considered the results as representing a post-operative

* Research Assistant in Surgery, University Department of Surgery, Royal Infirmary, Sheffield. Present address: Department of Surgery, Western Infirmary, Glasgow.

† Assistan Lecturer in Surgery, University Department of Surgery, Royal Infirmary, Sheffield.

‡ Principal Biochemist, Department of Chemical Pathology, United Sheffield Hospitals.

$\checkmark$ Registrar in Clinical Pathology, Department of Chemical Pathology, United Sheffield Hospitals. investigation at approximately four years. A gastric drainage procedure must be performed simultaneously with vagotomy, which by itself causes a high proportion of symptoms due to delayed gastric emptying. Gastrojejunostomy was combined with vagotomy in the present series, and the patients having pyloroplasty in the period under consideration have not been included as they were too few to merit detailed investigation. The study was designed to give as much information as possible without requiring more co-operation than could reasonably be expected from our patients. The tests were therefore restrictec to peripheral blood examination, estimation of serum-iron and serum-vitamin- $B_{12}$ levels, and measurement of vitamin- $B_{13}$ absorption and faecal fat excretion. In addition, the patients were asked about alimentary symptoms and weight changes before and after operation. Insulin tests to confirm completeness of vagotomy were not performed in all patients, but a recent study from this department suggests that vagal-nerve section was achieved in approximately $90 \%$ of patients (Ross and Kay, 1964).

\section{Clinical Material}

From a consecutive series of 120 patients with chronic duodenal ulcer treated by vagotomy and posterior gastrojejunostomy approximately four years previously, 25 were excluded because of death (5), reoperation (7), failure to attend (7), and distance from Sheffield (6). The 95 patients remaining for detailed investigation were 75 males and 20 females. Some were unable to undergo all the tests planned. All results described as "after operation" refer to the study of these patients approximately four years after vagotomy and gastrojejunostomy.

In order to have data with which to compare the results, information was taken from various sources, which are described in the next section. This information is called "control" data. 


\section{Methods}

Haemoglobin concentration was determined as oxyhaemoglobin in a grey-wedge photometer (King et al., 1948). The red-cell count was made in an EEL electronic counter. The immediate pre-operative haemoglobin level was known in 71 of the patients, but red-cell counts had not been performed routinely at the time of operation.

Control data were taken from the records of 185 healthy adults undergoing a routine haematological check during the period of our study; all had a haemoglobin estimation and 103 a red-cell count. These tests were made because the subjects, mainly nurses, radiographers, and industrial workers, were exposed to radiation risk, but in none was there any evidence of haematological abnormality.

Serum-iron concentration was estimated by Ramsay's (1953) method, using blood taken between 9 and 11 a.m. wherever possible. Control data were taken from a previous study by one of us (Baird et al., 1957) in which serum-iron levels had been estimated by the same method and in the same laboratory in a series of non-anaemic patients awaiting operation.

Serum-vitamin- $B_{12}$ levels were assayed by Dr. S. Varadi and Mr. A. Elwis in the Sheffield City General Hospital using the Euglena gracilis method (Ross, 1952).

Vitamin- $B_{12}$ absorption was estimated with radioactive ${ }^{58} \mathrm{Co}$ labelled vitamin $B_{12}$ by a urinary excretion method (Schilling, 1953). A $1-\mu \mathrm{g}$. dose of ${ }^{58} \mathrm{Co}$-labelled vitamin $\mathrm{B}_{12}$ (specific activity $1 \mu \mathrm{c} / \mu \mathrm{g}$.), contained in a single-dose ampoule obtained from the Radiochemical Centre, Amersham, was made up to approximately $23 \mathrm{ml}$. with distilled water. Exactly $20 \mathrm{ml}$. was immediately administered by mouth to the fasting patient and an intramuscular injection of $1 \mathrm{mg}$. of carrier vitamin $B_{12}$ was given simultaneously. The ${ }^{58} \mathrm{Co}$ content of all urine passed in the next 24 hours was measured in a ring counter made up of six $26-\mathrm{cm}$. Geiger-Müller tubes, using for the standard a measured aliquot from the original dose solution. The result was expressed as a percentage of the dose excreted in 24 hours. Control data were obtained during the period of study from 27 volunteer patients with no significant alimentary or haematological abnormality.

Faecal fat excretion was measured by the method of van de Kamer et al. (1949). Faeces were collected by the patient over a period of either four or five days by a previously described method (Cox, 1961). No special dietary restrictions were made except to be sure that the subject had an adequate dietary fat intake of more than $75 \mathrm{~g}$./day. The result was expressed as grammes of fat (as fatty acid) per day. Faecal fat estimations had been made by one of us (Cox, 1963) in identical manner in 52 patients with peptic ulcer before operation, and these data were available for comparison.

Body Weight.-The patient's weight at the time of operation and four years after vagotomy and gastrojejunostomy was recorded. In addition, the patients were asked to estimate their heaviest weight before operation, and this is referred to as "estimated best weight." The ideal weight according to sex, height, and age was taken from the Documenta Geigy Scientific Tables (1956).

\section{Results}

Peripheral Blood Studies.-The results for males and females are presented separately in this section and are summarized in Table I. The mean red-blood-cell counts in the patients after

TABLE I.-Haemoglobin and Red-cell Count Results in Controls and Patients Before and Four Years After Vagotomy and Gastrojejunostomy

\begin{tabular}{|c|c|c|c|c|c|c|c|}
\hline & & \multicolumn{3}{|c|}{ Haemoglobin (g./100 ml.) } & \multicolumn{3}{|c|}{ Red-cell Count } \\
\hline & & No. & Range & $\begin{array}{l}\text { Mean } \pm \\
\text { S.D. }\end{array}$ & No. & Range & $\begin{array}{c}\text { Mean } \pm \\
\text { S.D. }\end{array}$ \\
\hline \multicolumn{8}{|c|}{ Males } \\
\hline $\begin{array}{l}\text { Control subjects } \\
\text { Patients : }\end{array}$ & . & 111 & $13 \cdot 3-18 \cdot 0$ & $15 \cdot 4 \pm 1 \cdot 0$ & 88 & $4 \cdot 0-6 \cdot 4$ & $5 \cdot 1 \pm 0.5$ \\
\hline $\begin{array}{l}\text { Patients : } \\
\text { Before vagotomy }\end{array}$ & . & 56 & $8 \cdot 8-17 \cdot 5$ & $15 \cdot 3 \pm 1 \cdot 7$ & - & - & $0 \overline{10.7}$ \\
\hline \multicolumn{8}{|c|}{ Females } \\
\hline Control subjects & . & 74 & $|11 \cdot 8-16 \cdot 0|$ & $14.0 \pm 0.9$ & 15 & $4 \cdot 1-5 \cdot 3$ & $4 \cdot 6 \pm 0 \cdot 3$ \\
\hline $\begin{array}{l}\text { Patients : } \\
\text { Before vagotomy } \\
\text { After vagotomy }\end{array}$ & 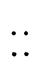 & $\begin{array}{l}15 \\
19\end{array}$ & $\begin{array}{l}9 \cdot 2-16 \cdot 6 \\
5 \cdot 7-16 \cdot 8\end{array}$ & $\begin{array}{l}13 \cdot 5 \pm 1 \cdot 8 \\
12 \cdot 8 \pm 2 \cdot 7\end{array}$ & $\overline{19}$ & $2 \cdot 4=5 \cdot 1$ & $4 \cdot \overline{ \pm 0} \cdot 6$ \\
\hline
\end{tabular}

vagotomy are not significantly different from those in the control subjects and will not be considered further. In both sexes the mean haemoglobin concentrations of the control subjects and of the patients before operation show no significant difference. In the males the mean of the patients after operation is not significantly different from the mean of the control subjects or patients before operation. In the females the mean of the patients after operation does not differ from that of the patients before operation but is significantly lower than the mean of the control subjects $(P<0.01)$. However, after operation five of the female patients reported such factors as menorrhagia and recent oral iron therapy, which tend to confuse the pattern; when the results of these patients are excluded from consideration the mean haemoglobin concentration in the remaining 14 is $13.6 \mathrm{~g} . / 100 \mathrm{ml}$. (S.D.=1.9), which is not significantly different from the mean of the control female subjects or of the females before operation. The distribution of haemoglobin levels (Table II) is approximately the same before and after operation. These results indicate that the haemoglobin

TABLE II.-Distribution of Haemoglobin Levels Before and Four Years After Vagotomy and Gastrojejunostomy

\begin{tabular}{|c|c|c|c|c|c|c|}
\hline \multirow{2}{*}{\multicolumn{3}{|c|}{ Haemoglobin (g./100 ml.) }} & \multicolumn{2}{|c|}{ No. of Males } & \multicolumn{2}{|c|}{ No. of Females } \\
\hline & & & $\begin{array}{c}\text { Before } \\
\text { Vagotomy } \\
(56)\end{array}$ & $\underset{\text { After }}{\text { Vagotomy }}$ & $\begin{array}{c}\text { Before } \\
\text { Vagotomy } \\
\text { (15) }\end{array}$ & $\begin{array}{c}\text { After } \\
\text { Vagotomy } \\
\text { (19) }\end{array}$ \\
\hline $\begin{array}{l}13.6 \text { and over } \\
11.6-13.5 \\
9.6-11.5 \\
9.5 \text { and less }\end{array}$ & $\begin{array}{ll} & \\
\cdots & \cdots \\
\cdots & \cdots\end{array}$ & $\begin{array}{l}\cdots \\
\cdots \\
\cdots\end{array}$ & $\begin{array}{r}49 \\
5 \\
1 \\
1\end{array}$ & $\begin{array}{r}64 \\
5 \\
1 \\
1\end{array}$ & $\begin{array}{l}9 \\
3 \\
2 \\
1\end{array}$ & $\begin{array}{l}9 \\
6 \\
2 \\
2\end{array}$ \\
\hline
\end{tabular}

Table III.-Details of Patients With Haemoglobin Levels Below $11.8 \mathrm{~g} . / 100$ ml. Four Years After Vagotomy and Gastrojejunostomy

\begin{tabular}{|c|c|c|c|c|c|c|c|c|}
\hline \multirow[b]{2}{*}{ Patient } & \multirow[b]{2}{*}{ Age } & \multicolumn{3}{|c|}{ Haemoglobin $(\mathrm{g} . / 100 \mathrm{ml})}$. & \multicolumn{3}{|c|}{ Other Results after Vagotomy } & \multirow[b]{2}{*}{ Other Clinical Features } \\
\hline & & $\begin{array}{l}\text { Before } \\
\text { Vagotomy }\end{array}$ & $\begin{array}{c}\text { After } \\
\text { Vagotomy }\end{array}$ & $\begin{array}{l}\text { After } \\
\text { Oral Iron }\end{array}$ & $\begin{array}{l}\text { Red-cell } \\
\text { Count }\end{array}$ & $\begin{array}{c}\text { Serum Iron } \\
(\mu \mathrm{g} . / 100 \mathrm{ml} .)\end{array}$ & $\left|\begin{array}{l}\text { Serum Vitamin } \\
\mathbf{B}_{12}(\mu \mu \mathrm{g} \cdot / \mathrm{ml} .)\end{array}\right|$ & \\
\hline
\end{tabular}

\begin{tabular}{|c|c|c|}
\hline \multicolumn{3}{|c|}{ Females } \\
\hline G.C. & . & $\cdots$ \\
\hline $\begin{array}{l}\text { G.R. } \\
\text { I.J. }\end{array}$ & . & $\cdots$ \\
\hline$\dot{\mathrm{B}}$. & $\because$ & 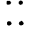 \\
\hline K.F. & .. & .. \\
\hline
\end{tabular}

\begin{tabular}{l|r|}
57 & $9 \cdot 2$ \\
44 & $11 \cdot 4$ \\
36 & $10 \cdot 8$ \\
47 & $14 \cdot 5$ \\
41 & -
\end{tabular}

\begin{tabular}{r|r}
9.9 & 12.4 \\
11.6 & 13.3 \\
8.3 & 13.1 \\
9.9 & 14.1 \\
5.7 & 12.3
\end{tabular}

$3 \cdot 8$
$4 \cdot 1$
$4 \cdot 1$
$3 \cdot 3$
$2 \cdot 4$

13
$\frac{92}{34}$
30

374
262
202
218
222

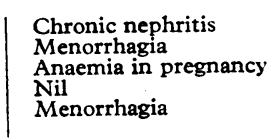

\begin{tabular}{|c|c|c|c|c|c|c|c|c|c|}
\hline $\begin{array}{c}\text { Males } \\
\text { F.G. } \quad \ldots\end{array}$ & $\cdots$ & 52 & $10 \cdot 6$ & $11 \cdot 1$ & $\overrightarrow{13.5}$ & $\begin{array}{l}5.0 \\
3.9\end{array}$ & $\begin{array}{l}25 \\
10\end{array}$ & $\begin{array}{l}137 \\
254\end{array}$ & $\begin{array}{l}\text { Piles } \\
\text { Nil }\end{array}$ \\
\hline
\end{tabular}


concentration is little altered four years after vagotomy and gastrojejunostomy.

Anaemia occurred in some patients before and after operation but not in the control subjects. Using as the criterion of anaemia haemoglobin levels below $13.3 \mathrm{~g} . / 100 \mathrm{ml}$. $(90 \%$ on Haldane scale) for men and $11.8 \mathrm{~g}$. $(80 \%)$ for women, the incidence of anaemia after operation in women $(26 \%)$ is significantly $(\mathrm{P}<0.05)$ higher than in men $(8 \%)$. However, anaemia is not necessarily a consequence of vagotomy and gastrojejunostomy, since patients with low haemoglobin levels after operation often had correspondingly low levels before operation (Table III), and factors unconnected with the operation were clearly important in several; these include bleeding piles, menorrhagia, and anaemia of pregnancy. No such factor could be detected in two patients (F. B. and S. L. in Table III). The anaemia of the post-operative patients was typical of iron deficiency. A course of oral iron therapy lasting for one to three months was sufficient to restore normal haemoglobin levels.

Serum-iron levels are presented separately for males and females (Table IV). The control data can be compared with

TABLE IV.- Serum-iron Levels in Control Subjects and Patients Four Years After Vagotomy and Gastrojejunostomy

\begin{tabular}{|c|c|c|c|c|c|c|}
\hline & & & & \multirow{2}{*}{$\begin{array}{l}\text { No. of } \\
\text { Results }\end{array}$} & \multicolumn{2}{|c|}{$\begin{array}{c}\text { Serum-iron Levels } \\
(u \mathrm{~g} . / 100 \mathrm{ml} .)\end{array}$} \\
\hline & & & & & Range & Mean \pm S.D. \\
\hline \multicolumn{7}{|c|}{ Males } \\
\hline $\begin{array}{l}\text { Control subjects } \\
\text { Patients : }\end{array}$ & $\cdots$ & . & . & 48 & $51-261$ & $143 \pm 39$ \\
\hline $\begin{array}{l}\text { Whole group } \\
\mathrm{Hb}>13 \cdot 3 \mathrm{~g} .\end{array}$ & $\cdots$ & $\cdots$ & $\because$ & $\begin{array}{l}64 \\
55\end{array}$ & $\begin{array}{l}10-197 \\
33-197\end{array}$ & $\begin{array}{r}99 \pm 38 \\
103 \pm 29\end{array}$ \\
\hline \multicolumn{7}{|c|}{ Females } \\
\hline $\begin{array}{l}\text { Control subjects } \\
\text { Patients : }\end{array}$ & . & . & . & 13 & $15-139$ & $97 \pm 34$ \\
\hline $\begin{array}{l}\text { Whole group } \\
\mathrm{Hb}>11 \cdot 8 \mathrm{~g} \text {. }\end{array}$ & $\because$ & $\begin{array}{l}\cdots \\
\cdots\end{array}$ & $\because$ & $\begin{array}{l}18 \\
12\end{array}$ & $\begin{array}{l}13-121 \\
30-121\end{array}$ & $\begin{array}{l}62 \pm{ }^{\prime} 32 \\
72 \pm 30\end{array}$ \\
\hline
\end{tabular}

the results in the patients after operation. The latter are divided into two groups: the first group includes all patients irrespective of their haemoglobin level ; the second group differs from the first in that anaemic patients are excluded, since anaemic subjects were also excluded from the control series (Baird et al., 1957). In male patients the mean serum-iron level after operation, even when the anaemic patients are excluded, is significantly lower than the control mean $(P<0.001)$. In female patients the mean serum-iron level after operation is also lower than the control mean $(P<0.01)$; however, when the results in the female patients with anaemia are excluded there is no significant difference between the controls and patients. When the results in females with additional complicating factors such as menorrhagia and recent iron therapy are also excluded the mean serum iron in the remaining 10 patients $(77 \mu \mathrm{g} . / 100 \mathrm{ml}$.) is not significantly lower than the control mean, which may be due to the small number of female patients after exclusion. Taking values below $60 \mu \mathrm{g} . / 100 \mathrm{ml}$. as abnormal, the incidence of hypoferraemia is $50 \%$ in women and $12.5 \%$ in men; this difference is significant $(P<0.001)$. Because of the low serumiron levels the data were studied to see if there was a fall in the serum-iron values with increasing time after operation. The mean values in patients grouped at monthly intervals showed a tendency to fall, but this could not be confirmed by statistical analysis, possibly because the time span of 37 to 57 months occupied by the patients in this study is too short to reveal a definite trend.

Serum-vitamin- $B_{12}$ levels in 83 patients after vagotomy and gastrojejunostomy were: 66 males, mean $305+$ S.D. $102 \mu \mu \mathrm{g} . /$ ml. (range 137 to $529 \mu \mu \mathrm{g}$ ), and 17 females, mean $314 \pm$ S.D. $132 \mu \mu \mathrm{g}$. (range 198 to $704 \mu \mu \mathrm{g}$.). The male and female means are not significantly different and correspond to the mean values in the laboratory where the assays were performed. Only one result was below the normal range of 150 to $850 \mu \mu \mathrm{g} . / \mathrm{ml}$.
The mean values in patients grouped at monthly intervals do not show a tendency to fall with time after operation. The tests of vitamin- $B_{12}$ absorption by the Schilling test indicate significantly reduced absorption in the patients when compared with the control subjects (Table $\mathrm{V}$ ). The mean value in the

TABLE V.-24-Hour Urinary Excretion of ${ }^{8} \mathrm{Co}$ Vitamin $B_{12}$ in Control Subjects and Patients Four Years After 'Vagotomy and Gastrojejunostomy

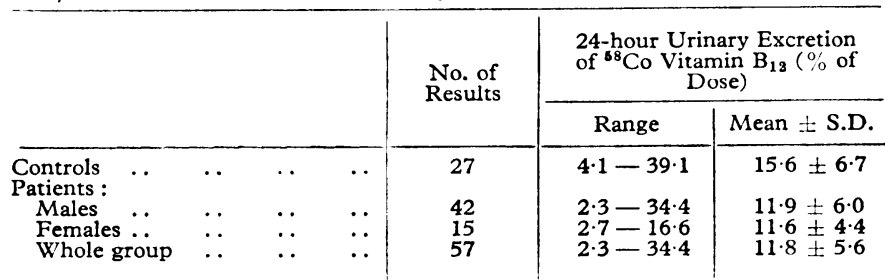

male patients does not differ significantly from the mean in the females. Taking 7\% of the dose as the lower limit of normal 24-hour excretion of radioactive ${ }^{58} \mathrm{Co}$, there were $19 \%$ abnormal results in the male patients and $13 \%$ in the female patients ; this difference is not significant.

Faecal Fat Excretion.-Taking a daily faecal fat excretion of $7 \mathrm{~g}$. or more as abnormal, the incidence of steatorrhoea in the men $(43 \%)$ is not significantly different from that in the women (33\%). The distribution of results (Fig. 1) shows that steatorrhoea was only mild in the majority. The mean faecal fat excretion of 84 patients after vagotomy and gastrojejunostomy (Table VI) is significantly higher than that of 52 patients with

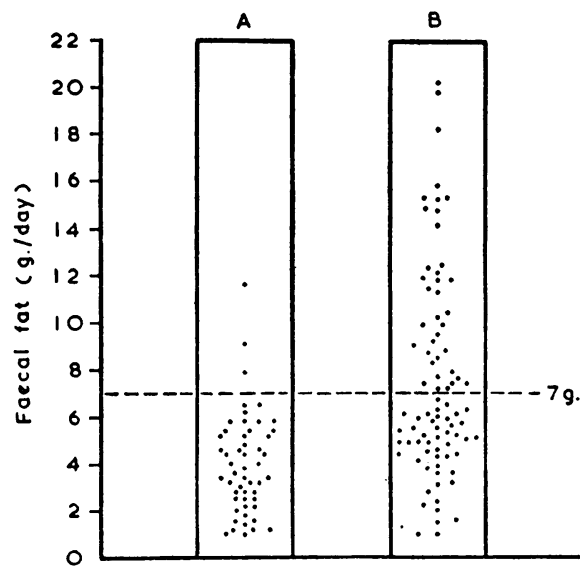

FIG. 1.-A comparison of faecal fat excretion in 52 patients with peptic ulcer before operation (A), with 84 patients four years after vagotomy and gastro;ejunostomy for chronic duodenal ulcer (B). The interrupted line at $7 \mathrm{~g}$. fat per day represents the upper level of normal faecal fat excretion. Mean daily fat excretion: A, $3.9 \mathrm{~g}$. ; $\mathrm{B}, 7.5$ g. $\mathrm{P}<0.0001$.

Table VI.-Faecal Fat Excretion in Control Subjects and Patients Four Years After Vagotomy and Gastrojejunostomy

\begin{tabular}{|c|c|c|c|c|c|c|}
\hline & & & & \multirow{2}{*}{$\begin{array}{l}\text { No. of } \\
\text { Results }\end{array}$} & \multicolumn{2}{|c|}{ Faecal Fat Excretion (g./day) } \\
\hline & & & & & Range & Mean \pm S.D. \\
\hline $\begin{array}{l}\text { Controls } \\
\text { Patients : }\end{array}$ & $\cdots$ & $\cdots$ & $\cdots$ & 52 & $1 \cdot 0-11 \cdot 6$ & $3 \cdot 9 \pm 2 \cdot 1$ \\
\hline Males .. & . & . & . & 65 & $1 \cdot 0-19 \cdot 8$ & $7 \cdot 3 \pm 4 \cdot 1$ \\
\hline Females ... & . & . & . & 19 & $1 \cdot 5-20 \cdot 2$ & $8.2 \pm 4.9$ \\
\hline Whole group & $\cdots$ & $\cdots$ & $\cdots$ & 84 & $1 \cdot 0-20 \cdot 2$ & \\
\hline
\end{tabular}

peptic ulcer before operation $(P<0.0001)$. The mean value in the males does not differ significantly from the mean in the females.

Weight Change.-The majority of patients reported a gain in weight between the time of operation and follow-up (Table VII). In the whole group there was a mean weight gain of $2.8 \mathrm{~kg}$; the mean gain in females $(5.5 \mathrm{~kg}$.) does not differ significantly from the mean gain in males $(2.1 \mathrm{~kg}$.). More 
detailed analysis indicates that weight change in the four years after operation depends in part upon the relation between the patient's estimated best weight before operation and his weight at the time of operation (Fig. 2). Patients whose weight at the

TABle VII.-Distribution of Weight Gains and Losses Four Years After

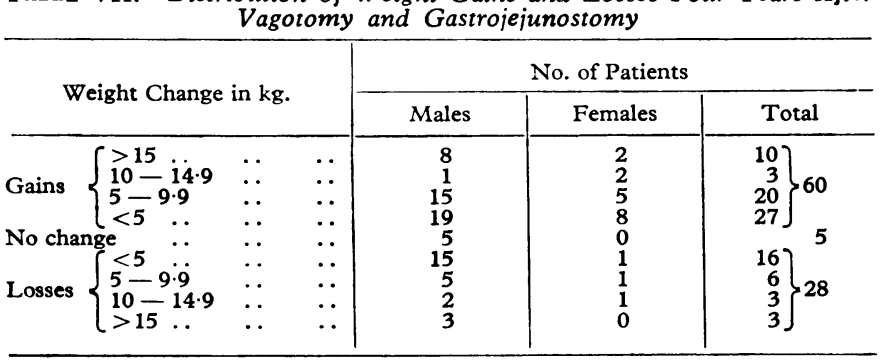

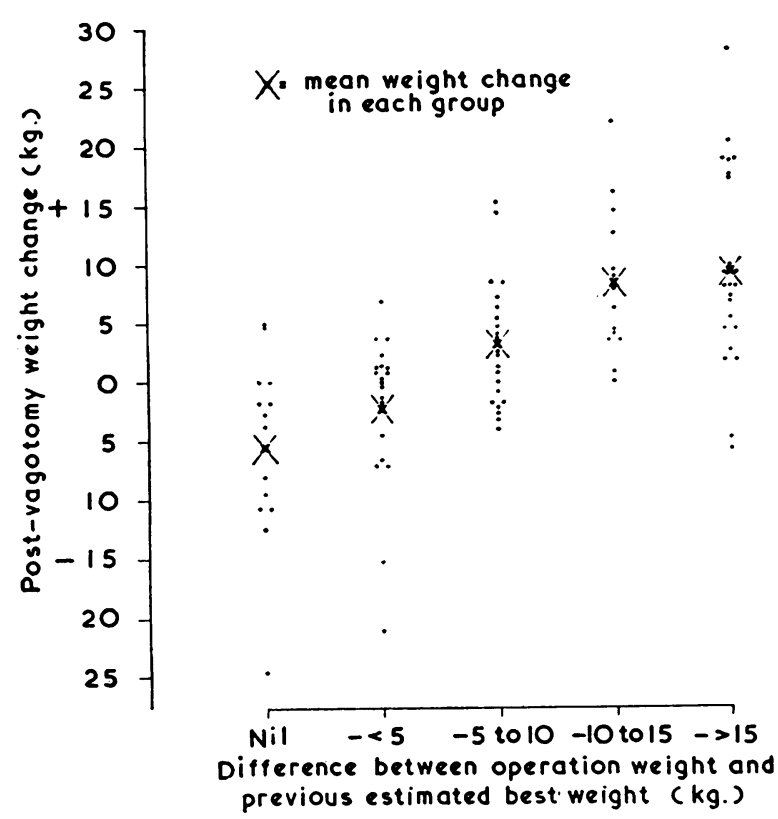

FIG. 2.-Relation between change in weight before and four years after vagotomy and gastrojejunostomy. On the horizontal axis, the patients are divided into groups according to difference between the patient's weight at the time of operation and his estimated previous best weight (those who gained weight up to the time oi operation are grouped with those showing no change). Analysis of variance shows a significant $(P<0.001)$ difference between the mean changes in the five groups, and inspection of difese these means shows a trend indicating that weight change af ter operation is inversely related to weight change before operation. The regression
line fitted to the ungrouped dat $\mathrm{a}$ has a coefficient of -0.580 (S.E.= line fitted to the ungrouped dat a has a coefficient of -0.
$0.084)$, which is highly significant $(P<0.001)$.

time of operation was most below their previous estimated best weight gained most weight after operation, and, conversely, patients at their estimated best weight at the time of operation lost most weight subsequently. The weight of the majority of patients four years after vagotomy and gastrojejunostomy remained below their estimated best weight before the operation. In four of the five groups shown in Fig. 2 the mean weight deficit ranges from 3.8 to $5.5 \mathrm{~kg}$. However, the group of patients who were more than $15 \mathrm{~kg}$. below their previous estimated best weight at the time of operation remained on average $12.5 \mathrm{~kg}$. below their previous best weight. The number of patients seriously below their ideal weight is much smaller four years after operation than before (Table VIII).

TABLE VIII.-Relation of Actual Weight to Ideal Weight Before and Four Years After Vagotomy and Gastrojejunostomy

\begin{tabular}{|c|c|c|c|c|c|}
\hline & \multicolumn{4}{|c|}{ Actual Weight as \% of Ideal Weight } \\
\hline & & $<80 \%$ & $80-90 \%$ & $90-110 \%$ & $>110 \%$ \\
\hline $\begin{array}{l}\text { No. of patients } \\
\text { Before vagotomy } \\
\text { After vagotomy.. }\end{array}$ & $\begin{array}{ll}. . \\
.\end{array}$ & $\begin{array}{r}19 \\
7\end{array}$ & $\begin{array}{l}26 \\
19\end{array}$ & $\begin{array}{l}53 \\
67\end{array}$ & $\begin{array}{l}2 \\
5\end{array}$ \\
\hline
\end{tabular}

\section{Discussion}

The main purpose of this study was to provide information relating to nutrition after vagotomy and gastrojejunostomy. The interval between operation and study was approximately four years, and a longer interval might modify the pattern of results. However, since information is almost entirely lacking on the effects of vagotomy on nutrition, this is a field which requires extensive investigation.

Post-operative insulin tests to confirm completeness of vagotomy were not performed routinely in this study, and the number of fully vagotomized patients is therefore uncertain. However, the results of augmented histamine and insulin tests in a recent study of patients treated by vagotomy in this department suggest that an adequate vagotomy was achieved in $90 \%$ of 100 consecutive patients (Ross and Kay, 1964). The same operative technique was used in our patients in whom an approximately similar finding might be expected. The likelihood that an inadequate vagotomy occurred in $10 \%$ of the patients in the present study detracts from the purely physiological interest of the results but does not annul their value in reflecting the overall pattern of change after the operation. Furthermore, it can reasonably be argued that the end-result of the operation is compounded of many variables which no amount of testing could evaluate fully-these include pre-operative gastrointestinal function, completeness or otherwise of vagotomy to stomach, and extragastric structures such as the pancreas, biliary tree, and small intestine, and size, position, and function of the gastro-enterostomy. An analogy can be drawn with comparable studies after partial gastrectomy in which the extent of gastric resection remains an unknown but important factor.

Haematological status has not previously been studied in detail after vagotomy, but abnormalities are generally believed to be uncommon. Haemoglobin levels below $90 \%$ have been reported in $14 \%$ of 40 patients eight years after vagotomy and gastrojejunostomy (Burge and Pick, 1958), and in approximately $10 \%$ of 209 patients studied 10 to 14 years after operation by Feggetter and Pringle (1963). In neither study was consideration given to possible sex differences or to haemoglobin values before operation. The present study suggests that low haemoglobin values develop only rarely within four years of vagotomy and gastrojejunostomy, since mean haemoglobin levels and the number of anaemic patients were the same as before operation. For the most part, anaemia occurred in the same individuals before and after operation, and only two patients known to have normal haemoglobin values at the time of operation were found to be anaemic at the time of our investigation. Although the cause of anaemia was not always obvious, it occurred more often in women, in whom factors such as menorrhagia and pregnancy seemed to be important. The good response to oral iton therapy implicated iron deficiency as the cause of the anaemia.

Although the haemoglobin levels were satisfactory, the possibility that iron deficiency is a complication of vagotomy and gastrojejunostomy, and may cause symptoms in later years, is suggested by the significantly reduced serum-iron concentrations. There may be a gradual depletion of iron stores after operation, but our results did not span a sufficient period of time to allow statistical confirmation of this. Longer-term studies might reveal a definite pattern and show whether anaemia can be expected to occur more frequently with the passage of time. However, Deller and Witts (1962) were unable to find a significant correlation between serum iron and time after partial gastrectomy, although a progressive fall in haemoglobin levels after this operation was demonstrated by these authors and by Baird et al. (1959). Since haemoglobin and serum-iron levels do not necessarily run parallel, both require further investigation after vagotomy and gastrojejunostomy.

Studies concerning vitamin $\mathrm{B}_{12}$ showed serum concentrations almost entirely within the normal range but a significantly reduced mean level of absorption in patients after vagotomy and 
gastrojejunostomy. These two findings are not incompatible, since the body's normal stores of vitamin $B_{12}$ are sufficient to cope with a considerable period of total deprivation (Schloesser et al., 1958). The degree of reduced absorption in the vagotomized patients was relatively small and most would be expected to replenish their stores at a rate sufficient to meet normal requirements. However, the detailed observations have to be viewed in the light of recent doubts concerning the reliability of the Schilling test used in the present study. Adams and Cartwright (1963) failed to obtain reproducible results in individual post-gastrectomy patients. If the same occurs after vagotomy and gastrojejunostomy, too much importance cannot be attached to the result in an individual patient, although the combined results of individual tests in a group of patients may still be a measure of absorptive capacity in the group as a whole.

Equally important questions arise from the observation of Deller et al. (1961) that the absorption of a dose of radioactive vitamin $B_{12}$ in post-gastrectomy patients varies with the method of administration of the dose. Similar observations have been made with the absorption of radioactive iron (Baird and Wilson, 1959) and radioactive fat (Cox, 1963). The same problems may exist in patients after vagotomy and gastrojejunostomy, in whom it would be of interest to study the influence on vitamin- $B_{12}$ absorption of such factors as food, intrinsic factor, and carbachol or histamine stimulation. Meanwhile the finding of reduced absorption in the present studies suggests that a megaloblastic type of anaemia might develop in a few patients some years after vagotomy and gastrojejunostomy.

The increased faecal fat excretion in the post-operative patients provides further evidence of some impairment of absorption after vagotomy and gastrojejunostomy. Mean faecal fat excretion was only slightly above the normal level, and the small associated calorie loss would be unlikely to have a recognizable effect on nutrition. The physiological explanation of the raised faecal fat is a subject of interest which merits further study. Butler (1961) has shown a similar incidence of increased faecal fat excretion after Polya partial gastrectomy (gastrojejunal anastomosis) but a much lower incidence after the Billroth I gastrectomy (gastroduodenal anastomosis); he also found that faecal fat excretion increased in the presence of a long afferent loop after the Polya gastrectomy. These observations could be accounted for by reduced pancreatic secretions and poor mixing of ingested food with the pancreatic enzymes in accordance with the work of Lundh (1958). The same considerations may apply after vagotomy and gastrojejunostomy, giving support to the current preference for pyloroplasty instead of gastrojejunostomy as the gastric drainage procedure. Some would favour the suggestion that the rise in faecal fat excretion is due to section of the vagus-nerve supply to the gall-bladder, pancreas, and small intestine. Although several investigators have studied the effects of vagal denervation on the function of these organs, a correlation between the effects observed and faecal fat excretion does not seem to have been demonstrated. In these circumstances, the subject remains confused and needs a more complete study of all the factors involved than has yet been attempted.

A study of the weight changes after operation showed that in the majority there was either no alteration or a gain and that the overall change was a mean gain of just under $3 \mathrm{~kg}$. Although these findings are favourable, weight changes after gastric surgery should also take account of weight changes before operation. The importance of this factor was clearly illustrated in the present study, which showed that patients who lost weight before operation tended to gain afterwards and that patients who did not lose weight before operation tended to lose weight afterwards. Although the majority of patients after operation were below what they considered to have been their best weight before operation, relatively few were substantially below their theoretical ideal weight according to height and age. Johnston et al. (1958) have reported approximately similar findings after partial gastrectomy, but the analysis of weight changes is not strictly comparable.

This study provides evidence of a satisfactory state of nutrition in most patients four years after vagotomy and gastrojejunostomy. Although certain abnormalities were discovered, most were only mild and some were not necessarily a direct result of operation. The data were examined to see if abnormal results were more frequent in certain patients, but no definite relationships could be established except for the concurrence of anaemia, hypoferraemia, and low red-cell counts. Abnormal results were not more common in patients with alimentary symptoms such as bile-vomiting and dumping, and no correlation could be found between faecal fat excretion and weight change or bowel habit. Perhaps the most important practical finding was the general tendency to low serum-iron concentrations. Patients may need regular haemoglobin estimations after vagotomy and gastrojejunostomy in order to detect the development of anaemia. Our findings indicate that this is a relatively minor problem requiring only oral iron therapy to obtain a rapid improvement in the haemoglobin level. Further studies are required to investigate the longer-term effects of vagotomy and gastrojejunostomy on nutrition. It would also be of interest to have comparable data in a series of patients after vagotomy combined with pyloroplasty in order to assess the relative merits of the drainage procedure employed.

\section{Summary}

Haematological status, intestinal absorption, and weight change were studied in 95 patients approximately four years after vagotomy and gastrojejunostomy.

Haemoglobin and serum-vitamin- $\mathrm{B}_{12}$ levels showed little alteration from normal, but serum-iron concentration was reduced. Absorption of vitamin $\mathrm{B}_{12}$ was reduced and faecal fat excretion was slightly raised. Most patients gained weight after the operation; there was an inverse relationship between change in weight before and after operation.

The significance of these findings is discussed.

We wish to thank the following: Professor A. W. Kay and Mr. W. J. Lytle for encouraging us to study their patients and for advice in the preparation of this paper ; Dr. E. K. Blackburn for providing control haemoglobin and red-cell-count data; Dr. H. P. Brody for allowing a study of his patients to obtain control vitamin-B absorption data ; Dr. S. Varadi for serum-vitamin-B ${ }_{12}$ estimations ; Miss H. M. Davis for-statistical advice; Miss C. Creasey for much secretarial help; Misses Z. Hinchliffe and H. Peck and Messrs. D. Bowen and D. Robertshaw for technical assistance; and the Tuberculosis Research Fund of the University of Sheffield for generous support.

\section{REFERENCES}

Adams, J. F., and Cartwright, E. J. (1963). Gut, 4, 32.

Baird, I. M., Blackburn, E. K., and Wilson, G. M. (1959). Quart. F. Med., 28, 21.

Podmore, D. A., and Wilson, G. M. (1957). Clin. Sci., 16, 463.

— Podmore, D. A., and Wilson, G. M. (1957). Clin.

Burge, H., and Pick, E. J. (1958). Brit. med. f., 1, 613.

Butler, T.' J. (1961). Ann. roy. Coll. Surg. Engl., 29, 300.

Cox, A. G. (1961). Brit. med. f., 2, 933.

(1963). Gastroenterology, 44, 275.

Deller, D. J., Germar, H., and Witts, L. J. (1961). Lancet, 1, 574.

- and Witts, L. J.' (1962). Quart. F. Med., 31, 71.

Documenta Geigy Scientific Tables, 1956, 5th ed., p. 255.

Feggetter, G. Y., and Pringle, R. (1963). Surg. Gynec. Obstet., 116, 175. Feggetter, G. Y., and Pringle, R. (1963). Surg. Gynec. Obstet., 116, 175. 1242 .

Kamer, J. H. van de, Huinink, H. Ten B., and Weyers, H. A. (1949). f. biol. Chem., 177, 347 .

King, E. J., Wootton, I. D. P., Donaldson, R., Sisson, R. B., and Macfarlane, R. G. (1948). Lancet, 2, 971.

Lundh, G. (1958). Acta chir. scand., Suppl. No. 231.

Ramsay, W. N M. (1953). Biochem. 7., 53, 227.

Ross, B., and Kay, A. W. (1964). Gastroenterology. In press.

Ross, G. I. M. (1952). F. clin. Path., 5, 250.

Rosh, G. I. M. (1952). f. clin. Path., 5, 250. 42,860

Schloesser, L. L., Deshpande, P., and Schilling, R. F. (1958). Arch. intern. Med., 101, 306. 